\title{
Pola Pemanfaatan dan Pemeliharaan Mangrove Masyarakat Pesisir di Kabupaten Bulukumba, Provinsi Sulawesi Selatan
}

\author{
Rosmiati'), Bakhrani Rauf( ${ }^{2}$, Faizal Amir $^{2)}$ \\ ${ }^{1)}$ Pertanian Universitas Indonesia Timur \\ ${ }^{2)}$ PPs Kependudukan dan Lingkungan Hidup, Universitas Negeri Makassar \\ Email: rosmiati@uit.ac.id

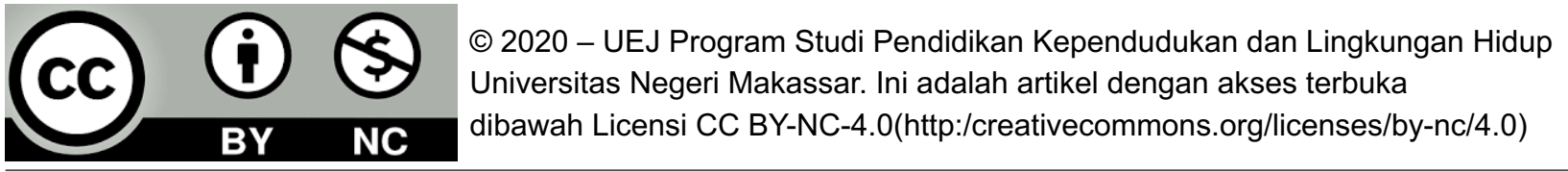

Abstrak.

Penelitian ini bertujuan untuk mendeskripsikan pola pemanfataan dan pemeliharaan mangrove masyarakat pesisir. Populasi penelitian adalah semua masyarakat yang berdiam di pesisir pantai Kabupaten Bulukumba. Sampel sebanyak 78 orang dipilih dengan metode purposive sampling. Analisis data menggunakan metode deskriptif kuantitatif dan analisis nilai. Selanjutnya hasil penelitian menunjukkan bahwa Pemanfaatan mangrove ditandai dengan nilai tertinggi pada indikator kawasan wisata dan perlindungan ombak. Sedangkan pemanfaatan kayu untuk bahan bakar dan bahan bangunan masih relatif rendah. Pada kajian pemeliharaan mangrove oleh masyarakat lokal ditemukan bahwa upaya penanaman memberikan nilai tertinggi. Sedangkan indikator pemusnahan dan pembuangan sampah relatif rendah. Namun demikian kegiatan ini harus dikendalikan karena dapat merusak ekosistem mangrove.

Kata kunci: Kawasan wisata, Pelindungan ombak dan pemusnahan

\section{PENDAHULUAN}

Peraturan Presiden Nomor 73 Tahun 2012 Tentang Strategi Nasional Pengelolaan Ekosistem Mangrove, pemerintah perlu melakukan upaya perlindungan, pelestarian dan pemanfaatan ekosistem mangrove secara lestari untuk kesejahteraan masyarakat. Lebih lanjut, Pasal 24 ayat (5) Peraturan Pemerintah Nomor 44 Tahun 2004 tentang Perencanaan Kehutanan mengatur bahwa Menteri Kehutanan berwenang menetapkan fungsi kawasan hutan berdasarkan kriteria. Dengan demikian, Menteri Kehutanan juga berwenang menetapkan fungsi kawasan hutan mangrove baik sebagai hutan lindung atau hutan produksi ataukah sebagai hutan konservasi.

Ekosistem mangrove berfungsi sebagai habitat berbagai jenis satwa. Ekosistem mangrove berperan penting dalam pengembangan perikanan pantai (Heriyanto dan Subiandono, 2012). Selain itu, kayu pohon mangrove dapat digunakan sebagai kayu bakar, bahan pembuatan arang kayu, bahan bagunan, dan bahan baku bubur kertas. Ekosistem mangrove mempunyai kemampuan dalam mengendalikan intrusi air laut melalui mekanisme pencegahan pengendapan $\mathrm{CaCO} 3$ oleh badan eksudat akar, pengurangan kadar garam oleh bahan organik hasil dekomposisi serasah, peranan fisik susunan akar mangrove yang dapat mengurangi daya jangkauan air pasang ke daratan, dan perbaikan sifat fisik dan kimia tanah melalui dekomposisi serasah (Kusmana, 
2015). Kerapatan mangrove berkontribusi terhadap tingkat luasan akresi, distribusi sedimen dantinggi elevasi permukaan (Kumara et. al, 2010).

Pemanfaatan kawasan hutan mangrove di Indonesia yang selama ini dikonversi sebagai lahan pertambakan, kenyataannya telah memberikan sumbangan yang sangat besar terhadap menurunnya luas areal hutan mangrove di Indonesia, baik itu secara kualitatif maupun kuantitatif. Permasalahan lain yang terkait dengan rusaknya hutan mangrove adalah konversi hutan mangrove yang diperuntukkan sebagai lahan pertanian, lahan perkebunan, kawasan pemukiman, bangunan dermaga dan berbagai kegiatan penambangan serta bangunan lainnya yang semakin semarak di kawasan pesisir. Namun demikian, kontribusinya masih jauh lebih kecil bila dibandingkan dengan dengan kegiatan pertambakan udang dan ikan (Sapruddin dan Halidah, 2012).

Salah satu daerah di Sulawesi Selatan yang memiliki kawasan hutan magrove adalah Kabupaten Bulukumba. Kabupaten Bulukumba memiliki kontribusi subsektor perikanan pada PAD cukup signifikan. Distribusi persentase PDRB Sub Sektor Perikanan berkontriubusi sebesar $10,84 \%$ pada tahun 2017 . Kontribusi ini merupakan terbesar ketiga setelah sektor perdagangan besar dan eceran sebesar 15,82\% dan sub sektor tanaman pangan sebesar 14,48 \%. Hal ini memperlihatkan bahwa sub sektor perikanan memiliki peranan penting dalam perekonomian daerah Kabupaten Bulukumba.

Meskipun demikian, kondisi ini tidak serta merta menyebabkan tingkat ekonomi dan kehidupan masyarakat pesisir menjadi lebih tinggi. Berdasarkan data Badan Pusat Statistik Provinsi Sulawesi Selatan, penduduk miskin di Kabupaten Bulukumba sampai dengan tahun 2015 sebanyak 33.360 orang atau 8,13\% dari total penduduk Kabupaten Bulukumba termasuk dalam kategori penduduk miskin. Jumlah ini mengalami penurunan jika dibandingkan penduduk miskin tahun 2014 yakni 34.190 orang atau 8,37 \% dari Jumlah Penduduk Kabupaten Bulukumba.

Kondisi ini dapat terjadi karena kontribusi dari masyarakat pesisir yang menempati wilayah pesisir cukup banyak dengan tingkat ekonomi yang rendah. Realitas menunjukan bahwa dari 12.122 orang yang berprofesi dalam sub sektor perikanan Tangkap di Kabupaten Bulukumba terdapat sebanyak 10.497 orang yang masih berprofesi sebagai Buruh Nelayan dan hanya sekitar 2.625 orang yang berprofesi sebagai pengusaha perikanan tangkap (Data Statistik Perikanan Bulukumba, 2018) Jumlah tersebut tersebar di 8 Keacamatan yaitu Kecamatan Ujungbulu, Kecamatan Ujung Loe, Kecamatan Bonto Bahari, Kecamatan Bonto Tiro, Kecamatan Herlang dan Kecamatan Kajang sebagai Wilayah bagian pesisir dan laut Kabupaten Bulukumba dengan panjang pantai $\pm 132,5$ km (Pemkab Bulukumba, 2017).

Salah satu kawasan hutan magrove terdapat di Kecamatan Ujungloe, tepatnya di Luppung Desa Manyampa. Kerusakan ekosistem mangrove, disebabkan aktivitas pertambangan liar yang marak terjadi di Kecamatan Ujung loe. Maraknya pertambangan yang terjadi mengakibatkan rusaknya lingkungan khususnya ekosistem mangrove karena bekas galian tambang yang dilakukan sebagian besar di tinggalkan begitu saja. Mengingat potensi multiguna sumber daya alam ini, maka merupakan keharusan bahwa pengelolaan hutan mangrove didasarkan pada ekosistem perairan dan darat, dalam hubungan dengan perencanaan pengelolaan wilayah pesisir terpadu. Menipisnya hutan mangrove perlu menjadi perhatian serius karena mangrove memainkan peranan penting dalam menjinakkan banjir pasang musiman (saat air laut pasang pada musim penghujan) dan sebagai pelindung wilayah pesisir. Selain itu, produksi primer mangrove berperan mendukung sejumlah kehidupan seperti satwa yang terancam punah, satwa langka, bangsa burung (avifauna) dan juga perikanan laut dangkal. 
Kondisi ini perlu menjadi perhatian utama khususnya ekosistem hutan mangrove sebagai ekosistem yang unik dan rawan. Ekosistem ini mempunyai fungsi ekologis dan ekonomis. Fungsi ekologis hutan mangrove antara lain pelindung garis pantai, mencegah intrusi air laut, sebagai habitat, tempat mencari makan (feeding ground), tempat asuhan dan pembesaran (nursery ground), tempat pemijahan (spawning ground) bagi aneka biota perairan, serta sebagai pengatur iklim mikro. Sedangkan fungsi ekonominya, antara lain penghasil keperluan rumah tangga, penghasil keperluan industri,sebagai objek wisata dan penghasil bibit (Utomo et. al, 2017).

Tujuan umum penelitian ini untuk mengetahui pola pemanfaatan dan pemeliharaan mangrove yang dilakukan oleh masyarakat lokal.

\section{METODE PENELITIAN}

Penelitian ini bersifan kuantitatif dengan penyebaran instrument kuesioner pada 78 responden. Responden dipilih secara purposive dengan pertimbangan masyarakat yang bermukim pada tepi pantai Desa Manyampa Kabupaten Bulukumba. Analisis data menggunakan metode deskriptif persentasi serta metode nilai. Metode nilai merujuk pada skala likert dengan nilai tertinggi 4 dan nilai terendah 1. Analisis nilai dilakukan dengan mengalikan frekuensi dan nilai tiap kategori kemudian dijumlahkan. Hasil penjumlahan menjadi acuan dalam pembahasan.

\section{HASIL DAN PEMBAHASAN}

\section{A. Pola Pemanfaatan}

Pengamatan di Kabupaten Bulukumba Kecamatan Ujungloe Desa Manyampa mangrove dimanfaatkan sebagai kayu bakar oleh masyarakat lokal masih sedikit. Adapun hasil analisis dapat dilihat pada tabel 1 .

Tabel 1. Pemanfaatkan Kayu Bakar

\begin{tabular}{lccc}
\hline \multirow{2}{*}{ Kategori } & \multirow{2}{*}{ Nilai } & \multicolumn{2}{c}{ Pemanfaatkan Kayu Bakar } \\
\cline { 3 - 4 } & & Frekuensi & Persentase \\
\hline Tidak Ada & 1 & 22 & $28 \%$ \\
\hline Sedikit & 2 & 24 & $31 \%$ \\
\hline Banyak & 3 & 16 & $21 \%$ \\
\hline Sangat Banyak & 4 & 16 & $21 \%$ \\
\hline
\end{tabular}

Sumber: Olah data, 2020

Berdasarkan tabel 1 di atas, dari 78 responden terdapat 22 orang (28\%) yang tidak memanfaatkan mangrove sebagai kayu bakar, selanjutnya 24 orang (31\%) yang masih sedikit memanfaatkan mangrove sebagai kayu bakar, dan 16 orang (21\%) sudah banyak memanfaatkan mangrove sebagai kayu bakar.

Pengamatan di Kabupaten Bulukumba Kecamatan Ujung Loe Desa Manyampa mangrove dimanfaatkan sebagai bahan bangunan oleh masyarakat lokal masih sedikit. Adapun hasil analisis dapat dilihat pada tabel .2.

Tabel 2. Pemanfaatan sebagai bahan bangunan

Kategori Nilai Bahan Bangunan




\begin{tabular}{lccc}
\hline & & Frekuensi & Persentase \\
\hline Tidak Ada & 1 & 16 & $21 \%$ \\
\hline Sedikit & 2 & 16 & $21 \%$ \\
\hline Banyak & 3 & 12 & $15 \%$ \\
\hline Sangat Banyak & 4 & 34 & $44 \%$ \\
\hline
\end{tabular}

Sumber: Olah data, 2020

Berdasarkan tabel 2 di atas, dari 78 responden terdapat 16 orang (21\%) yang tidak memanfaatkan mangrove sebagai bahan bangunan, selanjutnya 16 orang $(21 \%)$ yang masih sedikit memanfaatkan mangrove sebagai bahan bangunan, dan 12 orang (15\%) sudah banyak memanfaatkan mangrove sebagai bahan bangunan.

Pengamatan di Kabupaten Bulukumba Kecamatan Ujung Loe Desa Manyampa mangrove dimanfaatkan sebagai kawasan wisata oleh masyarakat lokal masih sedikit. Adapun hasil analisis dapat dilihat pada tabel 3 .

\begin{tabular}{lccc}
\multicolumn{2}{c}{ Tabel.3. Pemanfaatan sebagai kawasan wisata } \\
\hline \multirow{2}{*}{ Kategori } & \multirow{2}{*}{ Nilai } & \multicolumn{2}{c}{ Kawasan Wisata } \\
\cline { 3 - 4 } & & Frekuensi & Persentase \\
\hline Tidak Ada & 1 & 0 & $0 \%$ \\
\hline Sedikit & 2 & 2 & $3 \%$ \\
\hline Banyak & 3 & 28 & $36 \%$ \\
\hline Sangat Banyak & 4 & 48 & $62 \%$ \\
\hline
\end{tabular}

Sumber: Olah data, 2020

Berdasarkan tabel 3 di atas, dari 78 responden terdapat 0 orang $(0 \%)$ yang tidak memanfaatkan mangrove sebagai kawasan wisata, selanjutnya 2 orang (3\%) yang masih sedikit memanfaatkan mangrove sebagai kawasan wisata, dan 28 orang $(36 \%)$ sudah banyak memanfaatkan mangrove sebagai kawasan wisata.

Pengamatan di Kabupaten Bulukumba Kecamatan Ujung Loe Desa Manyampa, mangrove dimanfaatkan sebagai pelindung ombak oleh masyarakat lokal masih sedikit. Adapun hasil analisis dapat dilihat pada tabel 4.

Tabel.4. Pemanfaatan sebagai pelindung ombak

\begin{tabular}{lccc}
\hline \multirow{2}{*}{ Kategori } & \multirow{2}{*}{ Nilai } & \multicolumn{2}{c}{ Pelindung Ombak } \\
\cline { 2 - 4 } & & Frekuensi & Persentase \\
\hline Tidak Ada & 1 & 4 & $5 \%$ \\
\hline Sedikit & 2 & 2 & $3 \%$ \\
\hline Banyak & 3 & 24 & $31 \%$ \\
\hline Sangat Banyak & 4 & 48 & $62 \%$ \\
\hline \multicolumn{2}{l}{ Sumber: Olah data, 2020} & &
\end{tabular}

Berdasarkan tabel 4 di atas, dari 78 responden terdapat 4 orang (5\%) yang tidak memanfaatkan mangrove sebagai pelindung ombak, selanjutnya 2 orang (3\%) yang masih sedikit memanfaatkan mangrove sebagai pelindung ombak, dan 24 orang (31\%) sudah banyak memanfaatkan mangrove sebagai pelindung ombak. 
Pengamatan di Kabupaten Bulukumba Kecamatan Ujung Loe Desa Manyampa mangrove dimanfaatkan sebagai lahan tambak oleh masyarakat lokal masih sedikit. Adapun hasil analisis dapat dilihat pada tabel 5 .

Tabel.5. Pemanfaatan sebagai lahan tambak

\begin{tabular}{lccc}
\hline \multirow{2}{*}{ Kategori } & \multirow{2}{*}{ Nilai } & \multicolumn{2}{c}{ Lahan Tambak } \\
\cline { 3 - 4 } & & Frekuensi & Persentase \\
\hline Tidak Ada & 1 & 12 & $15 \%$ \\
\hline Sedikit & 2 & 23 & $29 \%$ \\
\hline Banyak & 3 & 26 & $33 \%$ \\
\hline Sangat Banyak & 4 & 17 & $22 \%$ \\
\hline
\end{tabular}

Sumber: Olah data, 2020

Berdasarkan tabel.5. di atas, dari 78 responden terdapat 12 orang (15\%) yang tidak memanfaatkan mangrove sebagai lahan tambak, selanjutnya 23 orang (29\%) yang masih sedikit memanfaatkan mangrove sebagai lahan tambak, dan 26 orang (33\%) sudah banyak memanfaatkan mangrove sebagai lahan tambak

Hasil rekapitulasi perkalian antara nilai dan frekuensi menjadi bahan penarikan kesimpulan tentang pengelolaan mangrove. Hasil perkalian tersebut disajikan pada gambar 1 .

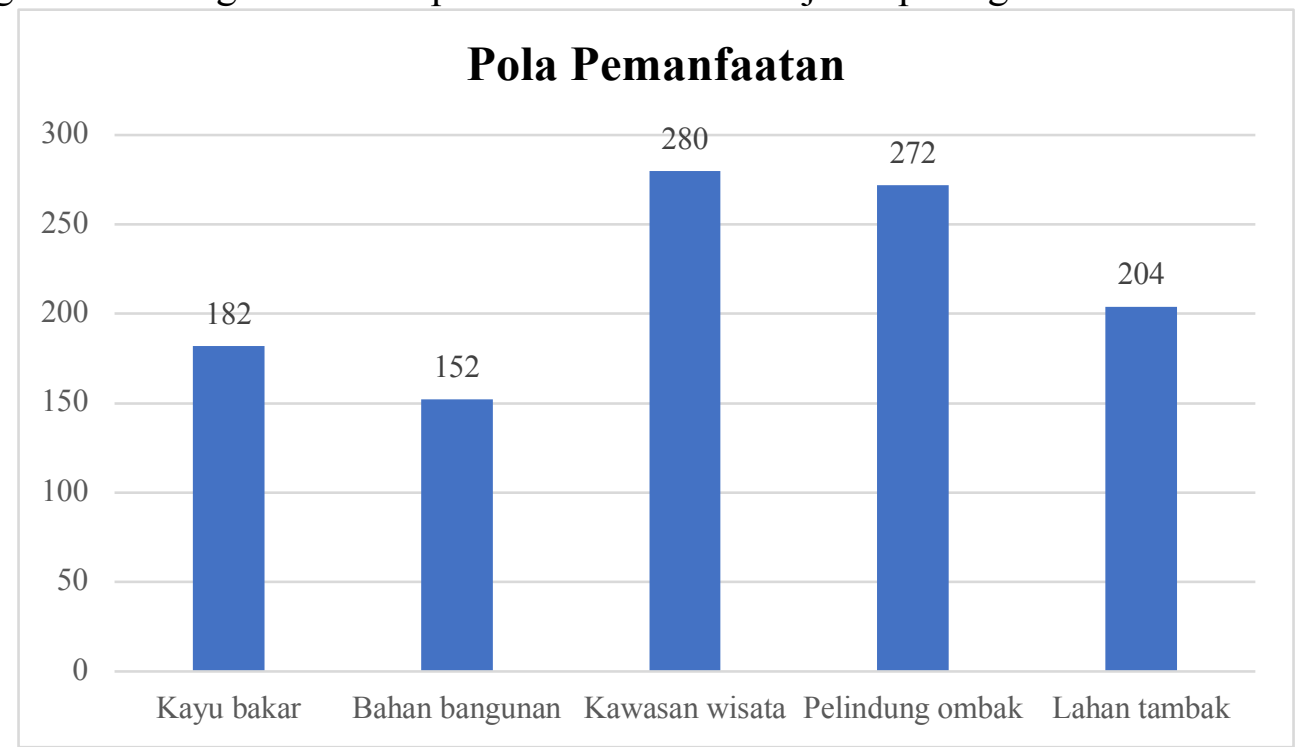

Gambar 1. Pola Pemanfaatan

Berdasarkan gambar 1. di atas menujukkan bahwa pemanfaatan mangrove memberikan nilai tertinggi yaitu sebesar 238 pada indikator kawasan wisata. Hasil ini memberikan gambaran bahwa masyarakat lokal menjadikan mangrove sebagai kawasan wisata. Selain itu, persepsi tentang manfaat pelindung ombak pada tanaman mangrove juga tinggi. Kedua indikator tersebut dengan nilai yang tinggi berindikasi pemanfaatan mangrove yang berkelanjutan. Sedangkan pemanfaatan kawasan mangrove untuk lahan tambak serta pengambilan kayu untuk bahan bakar dan bahan bangunan masih relatif rendah. Namun demikian kegiatan ini harus dikendalikan karena dapat merusak ekosistem mangrove.

\section{B. Pola Pemeliharaan}


Pola pemeliharaan mangrove di Kabupaten Bulukumba Kecamatan Ujung Loe Desa Manyampa dalam bentuk pemusnahan dapat dilihat dari hasil analisis pada tabel 6 .

Tabel.6. Pemeliharaan dalam bentuk pemusnahan

\begin{tabular}{lccc}
\hline \multirow{2}{*}{ Kategori } & \multirow{2}{*}{ Nilai } & \multicolumn{2}{c}{ Pemusnahan } \\
\cline { 3 - 4 } & & Frekuensi & Persentase \\
\hline Tidak Ada & 1 & 34 & $44 \%$ \\
\hline Sedikit & 2 & 30 & $38 \%$ \\
\hline Banyak & 3 & 12 & $15 \%$ \\
\hline Sangat Banyak & 4 & 2 & $3 \%$ \\
\hline
\end{tabular}

Sumber: Olah data, 2020

Berdasarkan tabel.6. di atas, dari 78 responden terdapat 34 orang (44\%) yang tidak memelihara mangrove dalam bentuk pemusnahan, selanjutnya 30 orang $(38 \%)$ yang masih sedikit memelihara mangrove dalam bentuk pemusnahan, dan 12 orang (15\%) yang memelihara mangrove dalam bentuk pemusnahan.

Pola pemeliharaan mangrove di Kabupaten Bulukumba Kecamatan Ujung Loe Desa Manyampa dalam bentuk penanaman dapat dilihat dari hasil analisis pada tabel 7.

Tabel.7. Pemeliharaan dalam bentuk penanaman

\begin{tabular}{lccc}
\hline \multirow{2}{*}{ Kategori } & \multirow{2}{*}{ Nilai } & \multicolumn{2}{c}{ Penanaman } \\
\cline { 3 - 4 } & & Frekuensi & Persentase \\
\hline Tidak Ada & 1 & 8 & $10 \%$ \\
\hline Sedikit & 2 & 12 & $15 \%$ \\
\hline Banyak & 3 & 26 & $33 \%$ \\
\hline Sangat Banyak & 4 & 32 & $41 \%$ \\
\hline
\end{tabular}

Sumber: Olah data, 2020

Berdasarkan tabel.7 di atas, dari 78 responden terdapat 8 orang $(10 \%)$ yang tidak memelihara mangrove dalam bentuk penanaman, selanjutnya 12 orang (15\%) yang masih sedikit memelihara mangrove dalam bentuk penanaman, dan 26 orang (33\%) yang memelihara mangrove dalam bentuk penanaman.

Pola pemeliharaan mangrove di Kabupaten Bulukumba Kecamatan Ujung Loe Desa Manyampa dalam bentuk pembuangan sampah dapat dilihat dari hasil analisis pada tabel 8 .

Tabel.8. Pemeliharaan dalam bentuk pembuangan sampah

\begin{tabular}{lccc}
\hline \multirow{2}{*}{ Kategori } & \multirow{2}{*}{ Nilai } & \multicolumn{2}{c}{ Pembuangan Sampah } \\
\cline { 2 - 4 } & & Frekuensi & Persentase \\
\hline Tidak Ada & 1 & 32 & $41 \%$ \\
\hline Sedikit & 2 & 32 & $41 \%$ \\
\hline Banyak & 3 & 12 & $15 \%$ \\
\hline Sangat Banyak & 4 & 2 & $3 \%$ \\
\hline
\end{tabular}

Sumber: Olah data,2020

Berdasarkan tabel 8 di atas, dari 78 responden terdapat 32 orang (41\%) yang tidak memelihara mangrove dalam bentuk pembuangan sampah, selanjutnya 32 orang (41\%) yang masih sedikit 
memelihara mangrove dalam bentuk pembuangan sampah, dan 12 orang (15\%) yang memelihara mangrove dalam bentuk pembuangan sampah.

Hasil rekapitulasi perkalian antara nilai dan frekuensi menjadi bahan penarikan kesimpulan tentang pemeliharaan mangrove. Hasil perkalian tersebut disajikan pada gambar 2 .

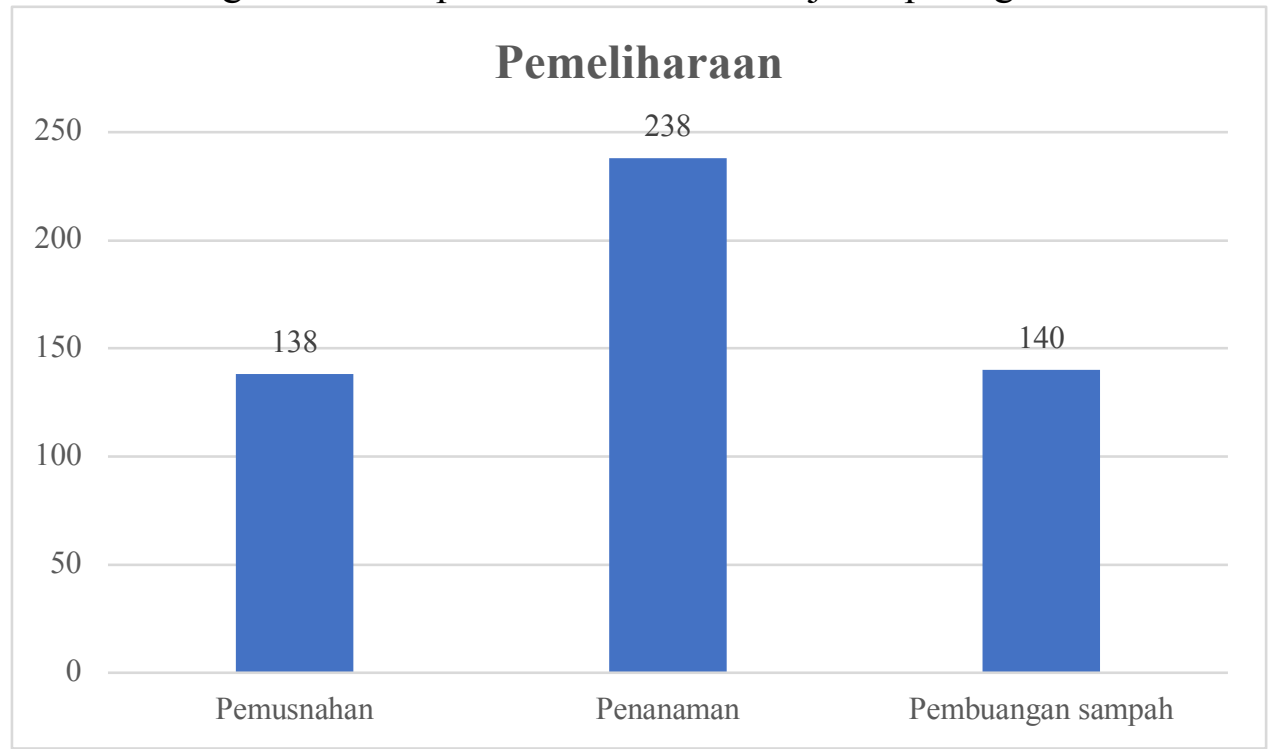

Gambar 2. Pola Pemeliharaan

Berdasarkan gambar 2. nampak bahwa pemeliharaan mangrove memberikan nilai tertinggi yaitu sebesar 238 pada indikator penanaman. Hasil ini memberikan gambaran bahwa aktivitas penanaman mangrove sebagai upaya rehabilitasi dilakukan oleh masyarakat. Selain itu terdapat pula kegiatan yang dapat merusak ekosistem mangrove seperti pemusnahan dan pembuangan sampah.

\section{KESIMPULAN}

Pemanfaatan mangrove ditandai dengan nilai tertinggi pada indikator kawasan wisata dan perlindungan ombak. Sedangkan pemanfaatan kayu untuk bahan bakar dan bahan bangunan masih relatif rendah. Pada kajian pemeliharaan mangrove oleh masyarakat lokal ditemukan bahwa upaya penanaman memberikan nilai tertinggi. Sedangkan indikator pemusnahan dan pembuangan sampah relatif rendah.Namun demikian kegiatan ini harus dikendalikan karena dapat merusak ekosistem mangrove.

\section{Referensi}

Heriyanto, N. M., \& Subiandono, E. (2012). Komposisi dan struktur tegakan, biomasa, dan potensi kandungan karbon hutan mangrove di Taman Nasional Alas Purwo. Jurnal Penelitian Hutan dan Konservasi Alam, 9(1), 023-032.

Kumara, M. P., Jayatissa, L. P., Krauss, K. W., Phillips, D. H., \& Huxham, M. (2010). High mangrove density enhances surface accretion, surface elevation change, and tree survival in coastal areas susceptible to sea-level rise. Oecologia, 164(2), 545-553. 
Kusmana, C. (2015). Integrated sustainable mangrove forest management. Jurnal Pengelolaan Sumberdaya Alam dan Lingkungan (Journal of Natural Resources and Environmental Management), 5(1), 1.

Peraturan Pemerintah Nomor 44 Tahun 2004 Tentang Perencanaan Kehutanan

Peraturan Presiden Nomor 73 Tahun 2012 Tentang Strategi Nasional Pengelolaan Ekosistem Mangrove

Saprudin, S., \& Halidah, H. (2012). Potensi dan Nilai Manfaat Jasa Lingkungan Hutan Mangrove Di Kabupaten Sinjai Sulawesi Selatan. Jurnal Penelitian Hutan Dan Konservasi Alam, 9(3), 213-219.

Utomo, B., Budiastuty, S., \& Muryani, C. (2017). Strategi Pengelolaan Hutan Mangrove Di Desa Tanggul Tlare Kecamatan Kedung Kabupaten Jepara. Jurnal Ilmu Lingkungan, 15(2), 117123. 